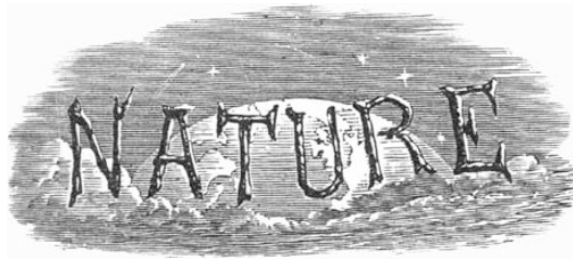

SATURDAY, FEBRUARY I2, I927.

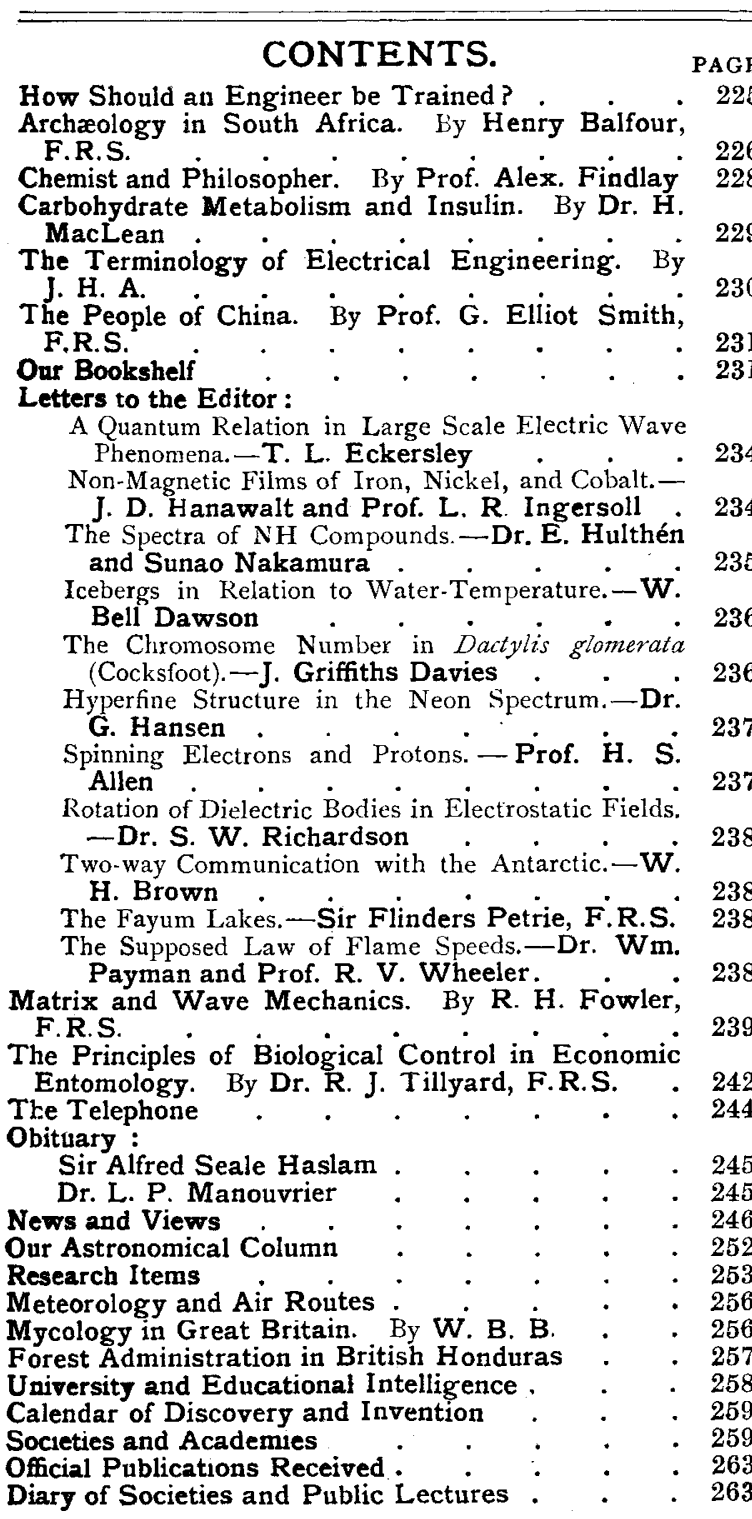

Editorial and Publishing Offices:

MACMILLAN \& CO., LTD.

ST. MARTIN'S STREET, LONDON, W.C.2.

Editorial communications should be addressed to the Editor. Advertisements and business letters to the Publishers.

Telephone Number: GERRARD 8830.

Telegraphic Address: PHUSIS, WESTRAND, LONDON.

\section{How Should an Engineer be Trained?}

AERY interesting discussion followed the paper $A$ on the training of engineers given by Sir Theodore Morison on Oct. 29 before the North-East Coast Institution of Engineers and Shipbuilders; and a report of it has now been published by the Institution. Those engaging in the discussion were representative of every branch of the profession, and while on some questions differences of opinion were manifest, there was a number of interesting points on which opinion appeared to be practically unanimous. Among these was the general agreement that all university students of engineering should have at least one year's works experience before beginning their university training, and that during this period evening classes should be taken in mathematics and physics with the view of conserving the habit of study engendered at school.

This plan has been advocated for many years by a number of those engaged in university teaching, and it is of interest to know that such procedure now appears to be so generally approved among practising engineers who have studied the question of engineering training. Its advantages are many. It brings a student to his university course with a realisation of the bearing of its scientific training on his future career, such as, in the majority of cases, increases notably his keenness in the work. It gives him, at the most plastic stage of his life, intimate contact with the working man whom in future years he will probably have to control, while the routine work and drudgery which is usually connected with this first period of training is likely to weed out any one whose real interests are not in engineering, and to give him the opportunity of withdrawing before much time has been wasted.

The discussion would have been important if this were the only point on which it has given a definite lead. The chief difficulty in applying it is that at present scarcely any engineering firm in Great Britain is prepared to take a youth for one year preliminary to his university training. If the North-East Coast Institution can persuade its members to adopt this course, arranging to take the youth back to complete his practical training after his graduation, it will have done a very important piece of work and made a real advance in the training of engineers.

Another point emphasised in the discussion was the somewhat haphazard method adopted by the majority of firms in the shop training of their special apprentices. In this connexion matters

No. 2989, VoL. 119] 
have improved during the past fifteen years or so, but even now the number of firms which has arranged for the apprentices carefully graded courses of shop training, and see that this training is adhered to, is almost negligibly small.

The sandwich system, in which a youth spends alternate periods of six months in works and at the university, received some support. It is, however, becoming more generally acknowledged that the value to a young engineer of a university course lies almost as much in the facilities which are afforded him for intercourse with fellow students in his own and especially in other branches of study, and in the general activities of student life, as in the technical training which he receives; and that the necessity for keeping terms different from those of the remainder of the university, which is necessary where the sandwich system is adopted, is, from this point of view, a serious objection to the system.

Another point on which opinion was almost unanimous has reference to the requirements for entry to a university course. It was generally felt that the present matriculation regulations operate adversely in the case of many excellent students whose education prior to a shop apprenticeship has been obtained at an elementary school, and whose later work at evening technical schools has shown them to be excellent engineering material.

While one or two universities have recognised the difficulty and have made special provision for such students, the majority of British universities still insist on the normal matriculation, except indeed for mature candidates, and there is little doubt that this insistence is barring each year from the universities a number of young engineers who would richly repay their training.

As Sir Theodore Morison pointed out, engineering is becoming more and more dependent yearly on scientific developments, and its future in Great Britain will depend largely on the type of mind that can be recruited into the profession, and on the methods adopted in the training of engineers. These methods will be investigated by a committee of the North-East Coast Institution of Engineers and Shipbuilders, as suggested by Sir Theodore. It is now more than fifteen years since engineering education was discussed fully at a conference arranged by the Institution of Civil Engineers, and changing conditions have made desirable the re-examination of its many aspects. The recommendations of the committee set up by the NorthEast Coast Institution will be awaited, therefore, with much interest.

No. 2989, VoL. 119]

\section{Archæology in South Africa.}

The Stone Age in Rhodesia. By Neville Jones. Pp. xiv $+120+22$ plates. (London: Oxford University Press, 1926.) 12s. $6 d$. net.

W R. NEVILLE JONES has earned our I thanks for having brought together the evidence of various stone age cultures as derived from Rhodesia, together with some of the dsta culled from a wider South African area. He has produced a very readable book which contains some valuable information. The whole problem of the South African stone age cultures is every day becoming more interesting and suggestive; and now that search for relics is being conducted upon more scientific lines, we can see the opening of an archæological chapter of high importance. The author's own researches at Sawmills (South Rhodesia) and at Tiger Kloof and Taungs (Cape Province) are valuable as evidencing culture-levels of lower- and mid-Palæolithic facies, which can be clearly distinguished and placed in sequence order. He very rightly urges the paramount necessity of attacking the archæological problems from the viewpoint of geological evidence. The numberless stone implements which may be picked up on the surface can teach us little unless we can identify the geological horizons to which they originally belonged. The spade alone can provide a clear idea as to the several cultures which may be distinguished, and their relative positions in the time-sequence. $\mathrm{Mr}$. Jones has worked conscientiously and thoughtfully, and his results help to advance the subject.

The value of the book is somewhat marred by unduly positive statements, which lack the support of evidence. To quote examples, which I hope may be modified in a future edition: On p. 12 (and cf. p. 19), in referring to mid-Palæolithic times, Mr. Jones says, "the core implement was thus gradually superseded by the flake implement, and finally disappeared altogether." In actual fact, core implements persisted in great abundance all through the Neolithic period, while within the Palæolithic period they form one of the most striking features of the Solutréan culture-phase. On p. 23 he says, "In Europe the stone implement, in Palæolithic times at any rate, was invariably made of flint," a statement which is quite untrue, since chert, quartzite, and other materials were frequently employed. On p. 19, in his diagram (adapted from Osborn), he asserts that the "bone industry begins" in Solutréan times. Why does he ignore the bone implements so char- 